\title{
The New Actors of Brazilian Foreign Policy
}

\author{
by Sean W. Burges \\ Australian National Centre for Latin American Studies \\ at the Australian National University, Australia
}
(PINHEIRO, Leticia and MILANI, Carlos R. S. (eds.). Política Externa Brasileira: As Práticas da Política e a Política das Práticas. Rio de Janeiro: Editora FGV, 2012)

$\mathrm{B}$ razilian foreign policy has reached a very interesting inflection point. The bureaucratic walls of the Itamaraty Palace so stoutly erected by the Baron of Rio Branco in 1902 are cracking. Where foreign policy used to be neatly circumscribed by the world of 'high politics' and external interaction by Brazilians limited to a small group of clearly defined actors, the situation today is very different. Itamaraty retains pride of place for the grand geopolitical thinking that often preoccupies the study of foreign policy, but the aspects of international affairs touching the lives of citizens everywhere are increasingly becoming the concern of line ministries, subnational governments, state agencies and private actors.

This is a bold claim with respect to Brazilian foreign policy, but one which accurately reflects the extent to which the technocratic minutia of specialist policy areas have not only internationalized, but increasingly interact with other areas of 'low' and 'high' politics. The immediate value of the individual chapters in this book is that they highlight the absurdity of any attempt to claim that Brazil's international affairs should remain the sole preserve of Itamaraty. Each of the five diverse sections of the book - human rights, culture, education, health, and paradiplomacy - immediately suggest that it is unreasonable to expect any relatively small organization, no matter how brilliant its staff, to retain mastery across such a wide range of sometimes highly technical specialties. Indeed, this is the very challenge with which Itamaraty is currently grappling. A more subtle approach is needed, one which involves complex bureaucratic positioning and intra-departmental coordination by Itamaraty to retain influence while also allowing Brazilian interests in these 
diverse areas to be advanced by the experts. Each of the chapters in this volume does an excellent job of describing what has happened.

Leticia Pinheiro and Carlos R. S. Milani introduce the book by focusing on the importance of technocratic expertise in many areas of contemporary international affairs. Their question then is whether or not it is reasonable to expect Itamaraty to have mastery over the diverse range of technical issues that are consequently found in foreign affairs, and if not, how are decisions made and policies pursued? In other words, the sharp distinction that Rio Branco drew between foreign and domestic policy is pointed out as being an increasingly artificial and unhelpful line. This in turn creates some issues for how we approach foreign policy analysis today, casting into doubt such accepted tricks as sharp divisions between levels of analysis and a tendency to oversimplify the nature and ambitions of actors.

The first section on human rights immediately takes up the theme of seeking a more complicated picture of how decisions are made and which actors are involved. Milani starts with a chapter looking at actors and agendas in Brazil's human rights foreign policy. He paints a picture of shifting understandings of what Brazil's position should be. While Itamaraty may ultimately remained the external voice expressing the national position, it certainly was not driving internal discussions or limiting how domestic politics drove policy change. The following chapter by Thiago Melamed de Menzes, a career diplomat with human rights experience in the UN system, pairs well with Milani's chapter, setting out how Itamaraty sought to adapt its practices to a contemporary scenario where a more participatory democratic process to issues like human rights policy is the norm. A careful tracing through the subtext paints a picture of bureaucratic attempts to control, direct, and defuse, but all done in a manner within the new bounds of having to allow outsiders into formerly exclusive policy consideration processes.

In section two attention is turned to the role of culture in foreign affairs. Mônica Leita Lessa, Miriam Gomes Saraiva and Dhiego de Moura Mapa begin with a chapter looking at the international cultural policies of the Lula government. Identity becomes an important consideration here with culture being used not only to present a desired and palatable Brazilian identity to the outside world, but also to reinforce a positive self-image to Brazilians and increase their comfort with the country's growing global presence. Itamaraty was intimately involved in this process, but in a sense more as the institution managing the external application of the policy; much of the formulation and pursuit of the underlying programs and policies came from the Ministry of Culture with a strong push from the presidency. The chapter by Minique Badaró on the State of Bahia's international cultural policies examines the extent to which sub-national governmental units are working to advance their specific agenda and interests distinct from the larger program 
run by Itamaraty. As Badaró points out, cultural promotion is an excellent method of raising a country's or state's international profile in a positive manner, making it something of a hotspot that can drive a multitude of activities ranging from tourism through foreign investment and trade to inter-departmental cooperation and collaboration.

Leticia Pinheiro and Gregory Beshara start the third section on education with a chapter examining how education policies have been used to help drive regional integration processes. As they point out, cooperation in the field of education plays an important role in efforts to build Mercosul and a wider South American space, which in turn points to the importance of education on identity formation and the solidification of national, let alone regional projects. The line between educational and foreign policy thus blurs, putting further implicit pressure on Itamaraty's attempts to direct Brazilian foreign policy. In some respects this chapter is more interesting for the questions it raises about foreign policy formulation than the role of education in foreign affairs, which neatly presages the compelling conclusion to the book. A more technical approach to education is taken by Alessandro Candeas, who effectively opens up interesting questions of South-South cooperation and the strengthening of educational and national capacity by looking at process of inter-state university cooperation.

André de Mello e Souza opens the fourth section by looking at Brazil's response to the AIDS epidemic. While this story is well known, the author aptly uses it to demonstrate not only how the line between national and international policy has blurred, but also how traditional realist views of international relations focused on the state as actor collapse when faced with pressure from multinational corporations and rising coalitions acting through organizations such as the WTO. Further blurring of policy division lines is introduced by discussion of how Brazil's successful anti-AIDS programming has evolved into something of a foreign policy engagement device across the global South. Paulo Marchiori Buss and José Roberto Ferreira build on this theme in the next chapter, discussing Brazil's experience with South-South cooperation in the health field, pointing out that while it has significantly enhanced Brazil's international engagement, much of the work has been driven from outside Itamaraty and is based in national principles such as a constitutional right to health that stand distinct from the realm of foreign policy.

The final section on paradiplomacy in some ways delivers the coup de grace to the notion of Itamaraty controlling Brazil's foreign policy. Two chapters, one by Mónica Salomón and the other by Alberto Kleiman, get to a very disturbing question for Itamaraty diehards: technically, only Itamaraty has the constitutional authority to engage in foreign negotiations, but what can be done if other levels of government decide to ignore this 'rule'? As is made clear in the two chapters, Brazil's states and municipalities are increasingly building their own sets of foreign relationships for a variety of reasons, including 
seeking development assistance, marketing themselves as a business and tourist destination, and collaborating with other like-minded areas to share policy and program experiences. While these are not questions of 'high' politics, they do fall into the realm of an active foreign affairs agenda.

This returns us to the point at the core of this important book. As Pinheiro and Milani note in their conclusion, the world of foreign affairs has become increasingly complicated, encompassing a far more diverse array of actors and issues than were at play during Rio Branco's time. This means that while Itamaraty is still central to Brazil's foreign policy, it can no longer be an isolated monopolistic voice; it has to actively and frequently engage with many other actors in policy areas that diplomats might formerly have considered irrelevant. As the editors conclude, foreign policy is now a public policy area with real domestic ramifications, not the apolitical sphere of national interest that Rio Branco saw as needing to be held above the daily political fracas. This suggests scholars should rethink some of the founding assumptions underlying their research agendas. This excellent volume provides us with a detailed explanation why and offers series of compelling questions for future research. 